\title{
CONTEMPORARY FLORISTIC CHANGES IN THE KARKONOSZE MTS.
}

\author{
JERZY FABISZEWSKI, BRONISŁAW WOJTUŃ \\ Department of Botany and Plant Physiology, Agricultural University \\ Cybulskiego 32, 50-205 Wrocław, Poland
}

(Received: February 22, 2001. Accepted: July 31, 2001)

\begin{abstract}
The paper presents the transformations of species composition in the main plant communities of the Karkonosze Mts. subalpine and alpine belts during the last 35 years. The investigations of floristic changes were performed in associations: Carici (rigidae)-Nardetum, Carici-Festucetum supinae, Crepidi-Calamagrostietum villose and Empetro-Vaccinietum. Signalized are also some vegetation transformations in the remaining belts. The progressing floristic degradation of plant communities in the subalpine and alpine belts consists in: (a) expansion of grasses, (b) decline of rare vascular plants, and (c) elimination of terricolous bryophytes and lichens. In spruce forest belts declining are species connected with old-growth spruce forests like: Listera cordata and Moneses uniflora. The changes of plant communities of low mountain swards (Nardetalia) caused by cessation of pasture and mowing in the cause of retreat of many rare plants, like e.g., Arnica montana. The main cause of the still lasting in the Karkonosze Mts. community transformations is the changes in soil environment connected with anthropogenic nitrogen fertilization. The large inflow of mineral nitrogen from the atmosphere $\left(1138 \mathrm{mg} / \mathrm{m}^{2} \mathrm{sum}\right.$ for vegetation season) is the reason of accelerated rate of decomposition of organic matter and intensified nitrification. The high content of nitrates in soil ( 5 times higher than in the Tatra Mts. swards) is the reason of expansion of graminoids, mainly Deschampsia flexuosa, Calamagrostis villosa and Carex bigelowii subsp. rigida. The overfertilisation of habitats causes the retreat of rare high mountain vascular plants and the decline of terricolous bryophytes and lichens.
\end{abstract}

KEY WORDS: Karkonosze Mts., flora, biodiversity, nitrogen mineralization, nitrification.

\section{INTRODUCTION}

The Karkonosze Mountains gained recently a bad reputation because of the lasting there, since the $60 \mathrm{~s}$, forest die-back. The die-back of spruce forests, which progresses mainly in the upper forest belt is, however, only one of the sharply appearing symptoms of drastic changes in the mountain vegetation during the last four decades. The elimination of the tree layer or its considerable loosening leads to noticeable changes in ecological conditions, the consequence of which is the transformation in the species composition of the floor vegetation (Fabiszewski et al. 1993; Fabiszewski, Wojtuń 1994). The recently performed investigations (Wojtuń et al. 1995, 1997) revealed that the lasting in the Karkonosze Mts. acidification and eutrophication of habitats exert an unfavourable influence not only upon the forests, but also upon communities of subalpine and alpine vegetation. The transformations of plant communities over the Karkonosze Mts. the forest line are, however, of a more subtle progress, as compared with the impressive die-back of high mountain spruce forests. They consist in a poorly noticeable, in the initial phase, expansion of one species (usually grass) with a parallel decline of rare species, frequently inconspicuous mountain plants. The latter are the most valuable in respect of their presence, as they decide on the floristic and geobotanical position of our mountains.

The Karkonosze Mts. plant communities have been penetratingly described on the turn of the 60 s (W. Matuszkiewicz, M. Matuszkiewicz 1969, 1974). The detailed information from these papers enable comparative studies on the old and present floristic composition of almost all the Karkonosze plant communities.

Our paper tends above all towards a characterization of modifications of the species composition of the main plant communities of the Karkonosze Mts. subalpine and alpine belts during the last 35 years. We cursorily signal also some of the vegetation changes in the remaining belts. The present paper presents also the most important, in our opinion, causes and effects of the still ongoing changes, which lead to loss of floristic diversity of this important European mountain range. 


\section{OBJECTIVES AND METHODS OF INVESTIGATION}

The objective of the contemporary investigations (19931995) were Matgrass swards Carici-Nardetum, subalpine and alpine swards Carici-Festucetum supinae alpinum, subalpine grasslands Crepidi-Calamagrostietum villose, and dwarf shrub heaths Empetro-Vaccinietum. Plots for investigation and their localization were selected according to the descriptions of W. and M. Matuszkiewicz (1969, 1974), trying also to stick to the phytosociological method of these authors. Our areas conform strictly to the places investigated in 1960 by the mentioned authors. The presently investigated areas were selected so as to overlap the previously investigated areas. The precise localization of the objectives is described in the papers by Wojtun et al. (1995, 1997).

On the basis of earlier investigations (Wojtuń et al. 1997) it was accepted that one of the more important reasons of the decline of the Karkonosze Mts. biodiversity are the changes in soil environment. Our soil investigations included measurements of mineral nitrogen content and rate of mineralization and nitrification. The netto mineralization and nitrification has been studied immediately in field on the basis of intact cores incubated in situ inside polyethylene bags (Piccolo et al. 1994). The mineral forms of nitrogen were extracted by means of water (nitrates) and a $6 \%$ solution of $\mathrm{KCl}$ (ammonium ions). Ammonium and nitrate concentrations were determined colorimetrically using an automated flow injection system (Braun+Luebe AutoAnalyzer). Ammonium-nitrogen was measured by the indophenol-blue method and nitrate-nitrogen was measured as $\mathrm{NO}_{2}$ following reduction with during the incuba- tion a cadmium column. Mineralization was calculated as the change in $\mathrm{NH}_{4}$ plus $\mathrm{NO}_{3}$.

For analyses of nitrogen conversion in the Karkonosze Mts. soils as control plots for the association CariciNardetum chosen were swards of Hieracio-Nardetum in the subalpine belt on the Hala Gąsienicowa in the Tatra Mts. (Mirek, Piękoś-Mirkowa 1995). They have a similar origin and a nearing floristic composition to the Karkonosze swards, particularly the mutual domination of grasses Nardus stricta and Deschampsia flexuosa. This community covers, so in the Tatra Mts. as in the Karkonosze Mts., the acidic podzol soils, build up of various kinds of granite.

Nomenclature follows Mirek et al. (1995).

\section{RESULTS}

\section{Floristic transformations in lower mountain belts}

An example of disappearance of rare plants, in result of whole ecosystem degradation of mountain spruce forests, are in the Karkonosze Mts. the deterioration of two species Listera cordata and Moneses uniflora (Fig. 1), connected with old spruce forests. They die irrevocably together with the disappearance of the oldest and best preserved mountain spruce forests (Fabiszewski, Jenik 1994).

The example of another vanishing species in the Karkonosze Mts. are Arnica montana and Hieracium aurantiacum (Fig. 2). Its stands shrunk drastically in the whole massif to ca. $10 \%$ as compared with old German data (Schube 1903). In general, the remove of range of that species (data from other parts of Europe, e.g. Schwabe 1990, Pegtel 1994; Brej, Fabiszewski 1997) may be decid-

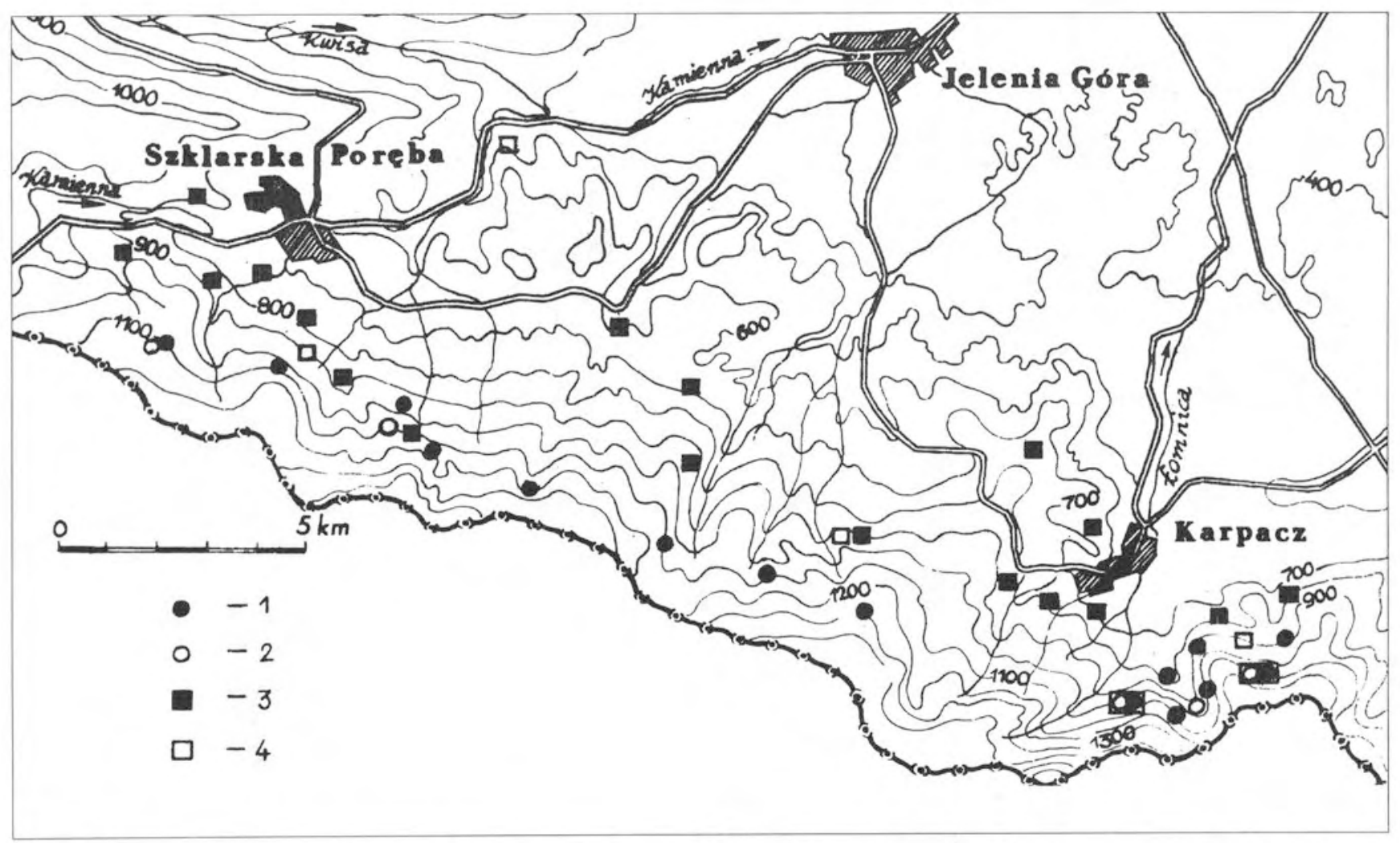

Fig. 1. Plant retreat from mountain spruce forest as an example of old-growth forest decline. 1 - Listera cordata (historical data - literature and herbaria), 2 - localities with the same species in 1994, 3 -Moneses uniflora (historical data - literature and herbaria), 4 - localities with the same species in 1994. 
1969

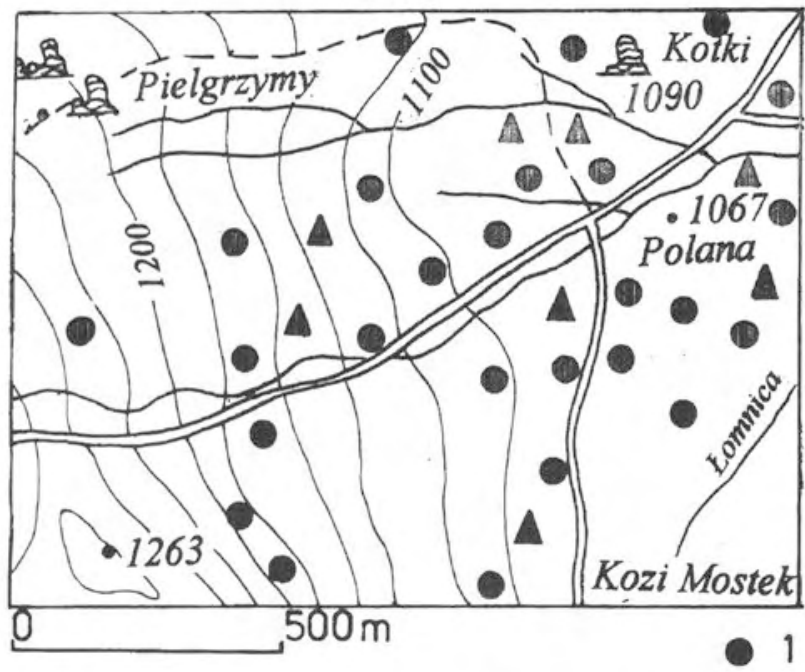

1994

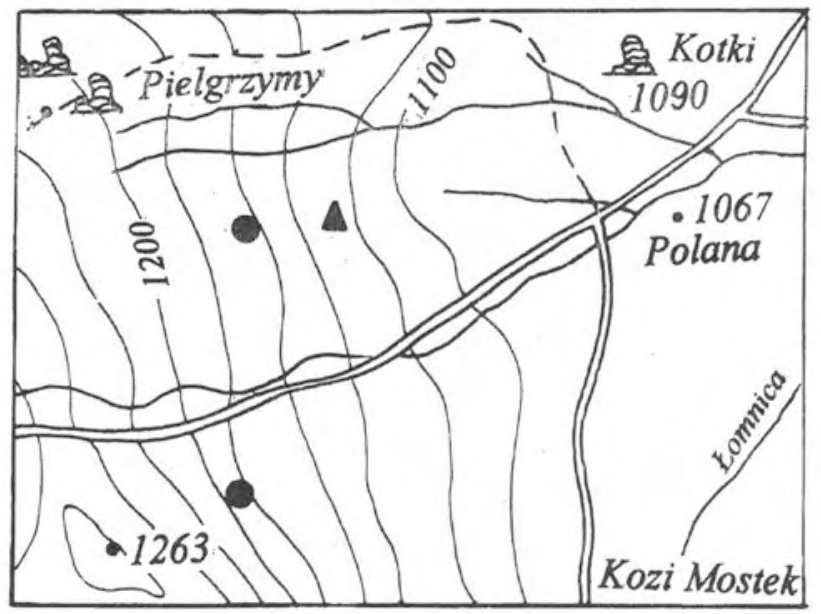

4 2

Fig. 2. Decline of Matgrass sward species in the last 25 years in a part of the Karkonosze Mts. 1 - Amica montana, 2 - Hieracium aurantiacum.

ed by chemical changes of soils covered by Nardetalia swards, noticed also in the Karkonosze Mts.

The comparison of losses of these and other valuable plants with data from European and Scandinavian mountains frequently does not allow to settle univocally the reasons of their decline. From among single factors in forest belts the transformation leading to an unfavourable forest thinning can be taken into consideration. Many of the declined species were bound with old forests of a natural and a more and more difficult for preservation ecological status. These concerns, among others, the increasingly rare pteridophytes and Dentaria genus from both the lower mountain belts connected with forests of order Fagetalia.

\section{Floristic changes in alpine and subalpine mountain belts}

The clearly visible effect of transformation of the Karkonosze Mts. high mountain phytocenoses are the changes in number of species (Table 1). The number of species decreased during 35 years on average by $30 \%$ in all the examined plant communities. The highest decrease was recorded in Matgrass swards Carici-Nardetum with a mean of 15.9 species in 1960 and only with ca. 7 species in 1995 . The lowest fall in number of species was observed in subalpine swards Carici-Festucetum supinae, from 14.0 in 1960 , to 12.4 species in 1995. Likewise in number of species, changes occurred also in the Shannon index value H', which decreased by ca. $20 \%$, on average from 2.5 to 2.00 .

A complete decline or substantial reduction of occurrence of many plant localities has caused such a consider- able decrease of species number in the Karkonosze Mts. subalpine and alpine communities. As can be seen in Table 2 , from among 20 species recorded with an at least $10 \%$ frequency in 1960, as many as 10 taxa were not found in 1995 and further 10 were met only sporadically. Among those not found were not only rare mountain species, typical for high mountain swards, as e.g., Luzula sudetica, Pulsatilla alba, Diphasium alpinum, Huperzia selago, but also plants quite lately frequent in the Karkonosze Mts., like Ranunculus platanifolius, Aconitum firmum, Geum montanum and Hypericum maculatum. Astounding is also the decline of some common species in swards as, for example, Vaccinium vitis-idaea and Solidago alpestris.

A natural difference between swards and dwarf shrub communities is the different growth forms (Fig. 3). For example, in Matgrass swards Carici-Nardetum plants of the graminoid form are dominating, while in dwarf shrub heaths Empetro-Vaccinietum predominating are dwarf shrubs, and in swards Carici-Fesucetum supinae there exists a distinct share of other forms, i.e., respectively forbs, dwarf shrubs and lichens. During the last 35 years in the communities at issue a considerable change in share of growth forms took place (Fig. 3). At present, other growth forms do not accompany the considerable share of graminoids in the investigated Carici-Nardetum swards. In subalpine swards Carici-Fesucetum supinae a distinct growth in share of graminoids has also been recorded, and at the same time a threefold decrease of share of dicot forbs and lichens. Together with a moderate growth of the cover

TABLE 1. Plot number, species number and Shannon index H' in 1960 and 1995 for five plant associations from subalpine and alpine belts in the Karkonosze Mts. Figures are means and SD. ${ }^{* * *} \mathrm{p}<0.001$, N.S. not significant.

\begin{tabular}{|c|c|c|c|c|c|c|}
\hline \multirow{2}{*}{ Plant communities } & \multicolumn{2}{|c|}{ Plot number } & \multicolumn{2}{|c|}{ Species number } & \multicolumn{2}{|c|}{ Shannon index $\mathrm{H}^{\prime}$} \\
\hline & 1960 & 1995 & 1960 & 1995 & 1960 & 1995 \\
\hline Carici-Nardetum & 22 & 94 & $15.9 \pm 3.0$ & $7.2 \pm 2.8^{* * *}$ & $2.41 \pm 0.25$ & $1.53 \pm 0.30^{\cdots}$ \\
\hline Crepidi-Calamagrostietum villosae & 16 & 36 & $21.8 \pm 6.4$ & $13.7 \pm 3.6^{\cdots *}$ & $2.75 \pm 0.34$ & $2.27 \pm 0.33^{\cdots}$ \\
\hline Carici-Festucetum supinae subalpine type & 13 & 58 & $14.0 \pm 3.0$ & $12.4 \pm 1.5$ N.S. & $2.41 \pm 0.21$ & $2.06 \pm 0.14^{\cdots *}$ \\
\hline Carici-Festucetum supinae alpine type & 8 & 19 & $16.8 \pm 1.3$ & $11.71 \pm .8^{\cdots * *}$ & $2.61 \pm 0.08$ & $2.17 \pm 0.13^{\cdots}$ \\
\hline Empetro-Vaccinietum & 20 & 30 & $17.5 \pm 2.8$ & $13.1 \pm 2.8^{\cdots}$ & $1.11 \pm 0.07$ & $0.88 \pm 0.64^{\cdots}$ \\
\hline
\end{tabular}


TABLE 2. Vascular plant species noted (frequency at least 10\%) in 1960, but not confirmed (+) or noted only sporadicaly $\left(^{*}\right)$ in 1995.

\begin{tabular}{|c|c|c|}
\hline Community: & Species & \\
\hline Carici-Nardetum & $\begin{array}{l}\text { Diphasiastrum alpinum } \\
\text { Huperzia selago } \\
\text { Luzula sudetica } \\
\text { Melampyrum sylvaticum } \\
\text { Pulsatilla alba }\end{array}$ & $\begin{array}{l}* \\
* \\
* \\
+ \\
+\end{array}$ \\
\hline Crepidi-Calamagrostietum villosae & $\begin{array}{l}\text { Aconitum firmum } \\
\text { Adenostyles alliariae } \\
\text { Cicerbita alpina } \\
\text { Geum montanum } \\
\text { Hieracium alpinum } \\
\text { Huperia selago } \\
\text { Hypericum maculatum } \\
\text { Leontodon hispidus } \\
\text { Potentilla aurea } \\
\text { Pulsatilla alba } \\
\text { Ranunculus platanifolius } \\
\text { Viola biflora }\end{array}$ & $\begin{array}{l}+ \\
* \\
+ \\
+ \\
+ \\
* \\
+ \\
+ \\
+ \\
* \\
* \\
*\end{array}$ \\
\hline $\begin{array}{l}\text { Carici-Festucetum supinae } \\
\text { - subalpine form }\end{array}$ & $\begin{array}{l}\text { Diphasiastrum alpinum } \\
\text { Primula minima } \\
\text { Pulsatilla alba } \\
\text { Solidago virgaurea }\end{array}$ & $\begin{array}{l}+ \\
* \\
* \\
*\end{array}$ \\
\hline $\begin{array}{l}\text { Carici-Festucetum supinae } \\
\text { - alpine form }\end{array}$ & $\begin{array}{l}\text { Pulsatilla alba } \\
\text { Solidago virgaurea } \\
\text { Vaccinium vitis-idaea }\end{array}$ & $\begin{array}{l}* \\
* \\
*\end{array}$ \\
\hline Empétro-Vaccinietum & $\begin{array}{l}\text { Empetrum hermaphroditum } \\
\text { Huperzia selago } \\
\text { Pulsatilla alba } \\
\text { Solidago virgaurea }\end{array}$ & $\begin{array}{l}* \\
* \\
* \\
*\end{array}$ \\
\hline
\end{tabular}

of graminoid species in phytocenoses Empetro-Vaccinietum there occurred a drastic decrease in presence of bryophytes and lichens.

Conversion of soil nitrogen in the Tatra Mts. and Karkonosze Mts. swards

In spite of similarities in nitrogen dynamics in high mountain swards, we recorded significant differences between the Tatra Mts. and Karkonosze Mts. areas. These differences consist in the following anthropogenic differences of the Karkonosze Mts.:

- the inflow of nitrogen in the ammonium and nitrate forms is almost three times higher in the Karkonosze Mts. than in the Tatra Mts. (1138 and $369 \mathrm{mg} / \mathrm{m}^{2}$ respectively). The proportions between the mentioned forms in both the mountain ranges are identical.

- the mean content of mineral nitrogen in soils of both the areas was in the vegetation season $1.30 \mathrm{mg} / 100 \mathrm{~g} \mathrm{s.m}$. (Table 3 ). In both the areas ammonium nitrogen is predominating. The share of nitrates in the total content of mineral nitrogen is small, however, it is emphasized that in Karkonosze Mts. swards Carici-Nardetum this anion occurred in five time higher amounts as compared with the Hieracio-Nardetum in the Tatra Mts.

- field mineralizatin of nitrogen calculated as accumulation of ions $\mathrm{NH}_{4}$ and $\mathrm{NO}_{3}$ in soil differs distinctly in the two studied communities in the Tatra Mts. and Karkonosze Mts. The increment of mineral nitrogen in soils of Karkonosze Mts. swards was three times higher than in
TABLE 3. Nitrogen deposition (monthly average and sum for vegetation season) in the Tatra Mts. and the Karkonosze Mts. ecosystems in 19921993 and amounts of nitrogen in soil of Hieracio-Nardetum and CariciNardetum (values are means for vegetation season of 1995).

\begin{tabular}{lccc}
\hline & $\mathrm{N}^{-\mathrm{NH}_{4}}$ & $\mathrm{~N}^{-\mathrm{NO}_{3}}$ & $\mathrm{~N}\left(\mathrm{NH}_{4}+\mathrm{NO}_{3}\right)$ \\
\hline $\begin{array}{l}\text { Monthly average } \\
\text { for vegetation season }\left(\mathrm{mg} / \mathrm{m}^{2}\right)\end{array}$ & & & \\
HALA GASIENICOWA & & & \\
KARKONOSZE $^{2}$ & 50 & 49 & 92 \\
& 152 & 133 & 285 \\
Sum for vegetation season $\left(\mathrm{mg} / \mathrm{m}^{2}\right)$ & & & \\
HALA GASIENICOWA $^{1}$ & 201 & 195 & 369 \\
KARKONOSZE $^{2}$ & 607 & 531 & 1138 \\
& & & \\
$\begin{array}{l}\text { Amounts in soil (mg/100 g s.m.) } \\
\text { Hieracio-Nardetum }\end{array}$ & 1.31 & 0.019 & 1.33 \\
Carici-Nardetum & 1.19 & 0.097 & 1.29 \\
\hline
\end{tabular}

${ }^{1}$ according to Wathne et al. 1993

${ }^{2}$ according to Zwoździak et al. 1995 and Kmieć et al. 1994

Tatra Mts. swards (Fig. 3). The dominant form of nitrogen which was accumulated during field mineralization in Carici-Nardetum (Karkonosze Mts.) were the nitrates, whereas in Hieracio-Nardetum soils (Tatra Mts.) ammonium ions were predominating.

\section{DISCUSSION}

The Karkonosze Mts. plant communities are for several decades under a strong pressure of various stress factors connected with air pollution containing hydrogen ions, nitrogen and sulphur compounds and heavy metals. The transported pollutants produce a number of chain changes, beginning with abiotic environment and stopping at floristic changes. Unfortunately, we do not know much about changes taking place in whole ecosystems. The most dangerous from among the progressing here processes of ecosystemic influence are eutrophication and acidification of natural habitats (Fabiszewski, Wojtuń 1994; Żołnierz et al. 1994; Wojtuń et al. 1997).

\section{Degradation of vegetation}

Quantitative and qualitative investigations of the floristic composition of plant communities and changes in share of growth forms in various associations in the years 19601995, as well as, investigations of nitrogen conversion in soil revealed a number of phenomena, which add up to a progressing process of floristic degradation in plant communities, particularly of the subalpine and alpine belts. Among the most significant ones belong: the expansion of grasses, decline of rare vascular plants and the elimination of terricolous bryophytes and lichens.

The expansion of grasses and grass-like species progresses with various intensity in all the studied phytocenoses. The species of highest expansiveness is Deschampsia flexuosa, the cover of which since 1960 till to-day increased 3-4 times almost in all the communities. A high expansiveness shows also the sedge Carex bigelowii subsp. rigida, which expands most in Matgrass swards Carici-Nardetum.

Together with the expansion of grasses and decline of the ground layer of cryptogamic plants in phytocenoses, 


\section{Carici - Festucetum supinae subalpine form}
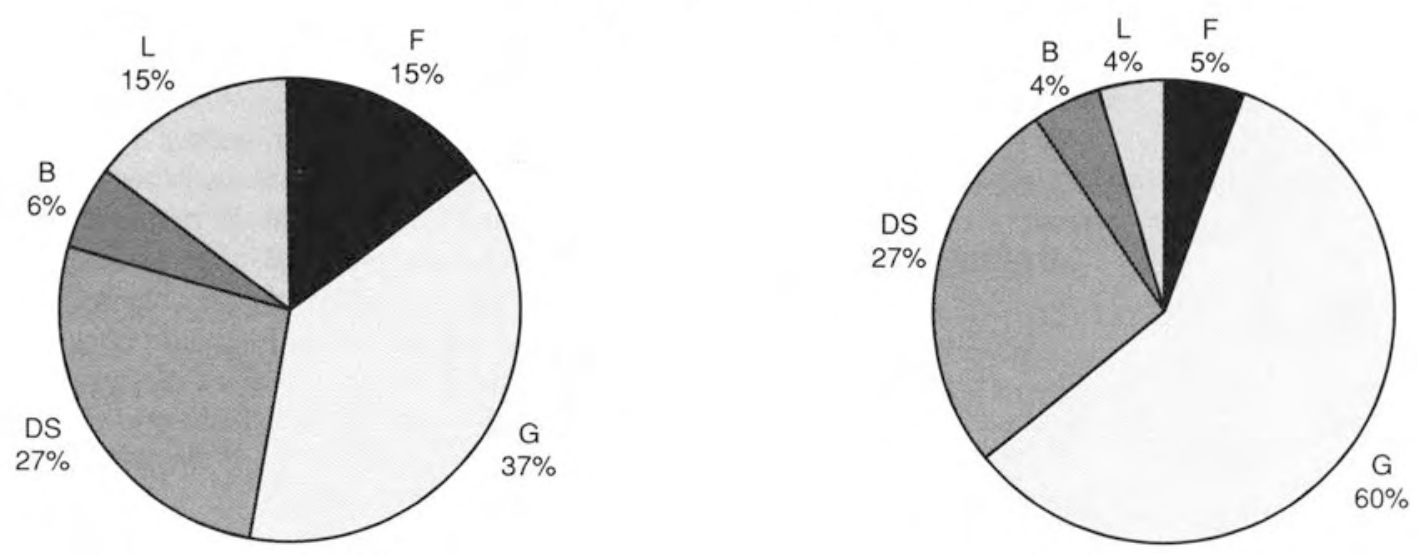

Carici (rigdae) - Nardetum
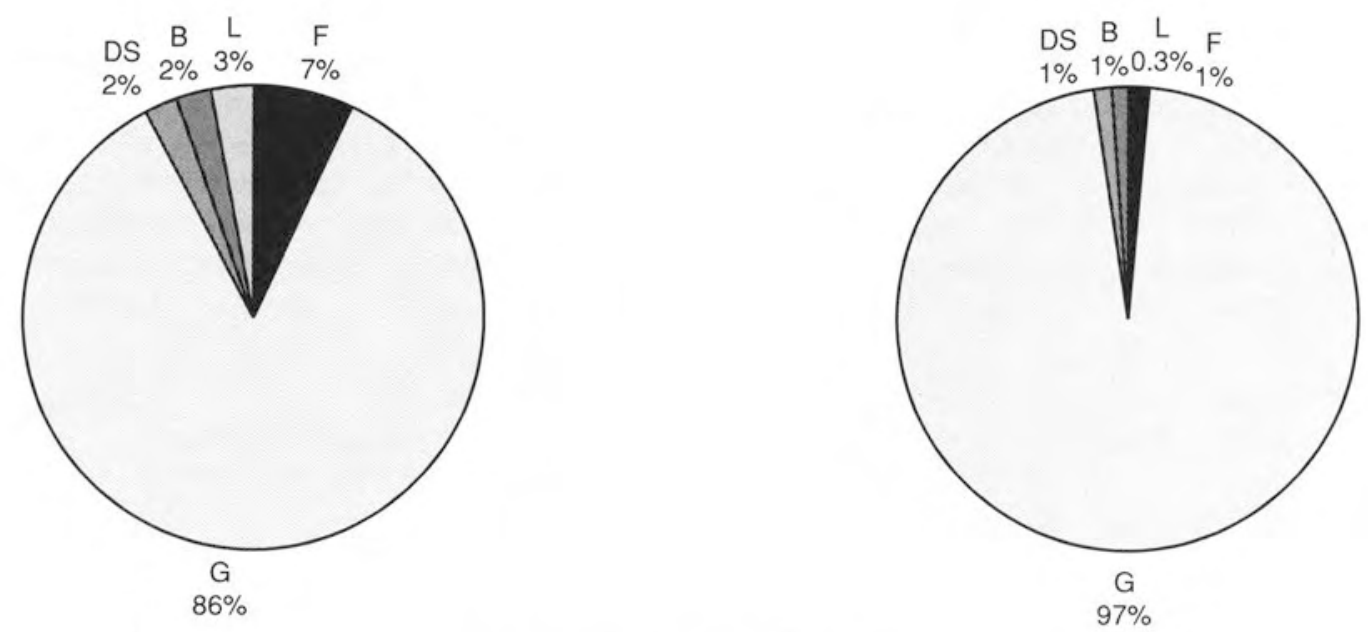

\section{Empetro - Vaccinietum}
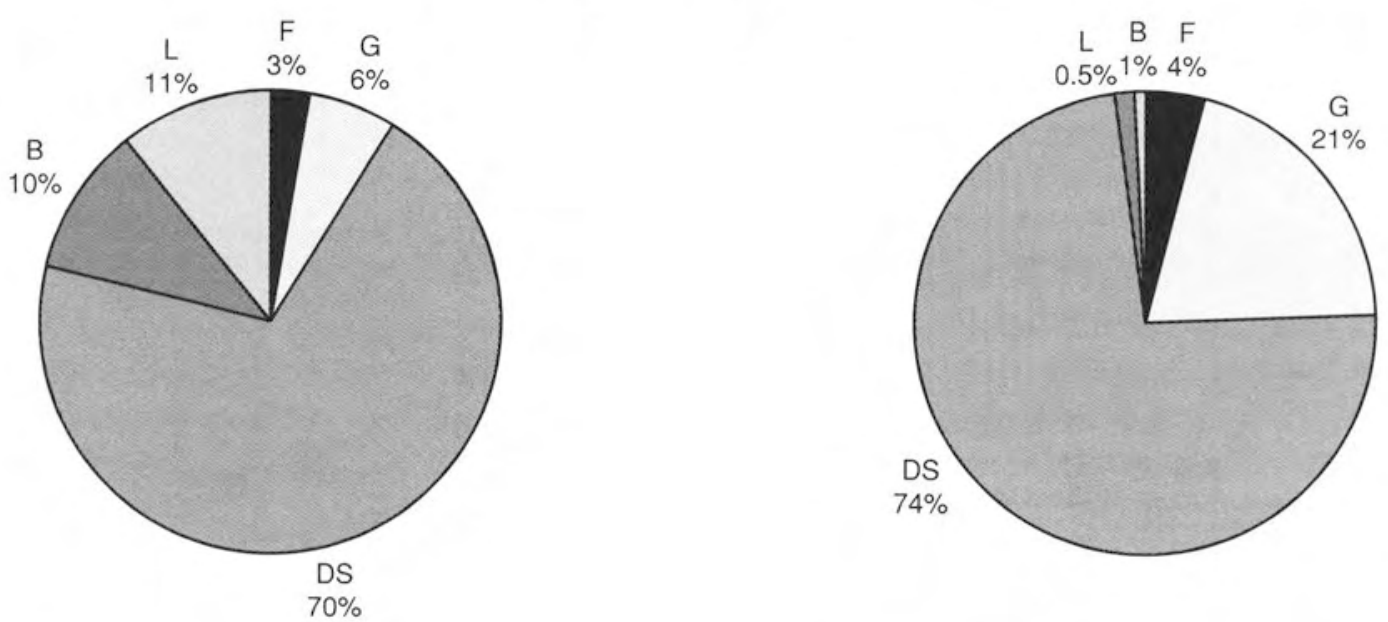

Fig. 3. Plant functional growth forms in three subalpine plant communities in 1960 and 1995. L - lichenes, B - bryophytes, G graminoids, F - forbs, DS - dwarf shrubs. 


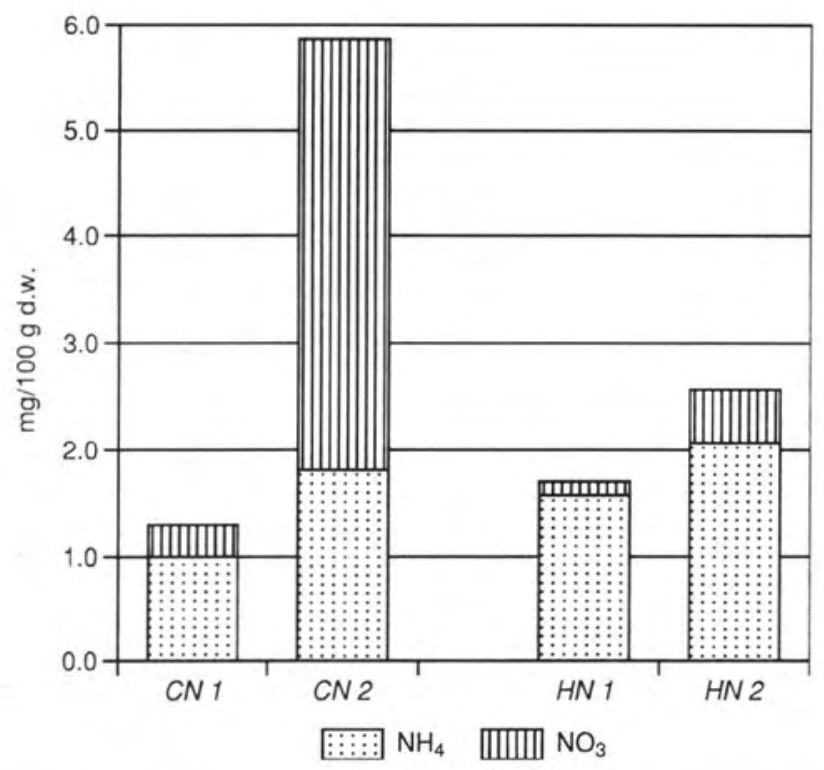

Fig. 4. Soil concentration of ammonium and nitrate in different sward associations in the Karkonosze Mts. and Tatra Mts. (measure of 62 days of mineralization). $\mathrm{CN}$ - Carici-Nardetum, $\mathrm{HN}$ Hieracio-Nardetum, 1 - start of mineralization (August 5, 1995), 2 - end of mineralization (October 5, 1995).

particularly alarming for florists and conservators is the decline of many vascular species (Table 2). Many plants which occurred (some of them rarely) in 1960, but in as many as 79 phytosociological releves, have now not been found, despite 237 releves have been made. To these species belong, among others, Rhinanthus alpinus, Amica montana, Leucorchis albida, Lycopodium clavatum,
Hypochoeris uniflora, Crepis conyzifolia, and Carex atrata. Most of the mentioned species represent the typical high mountain flora, characteristic for the upper belt of the Karkonosze Mts., the decline of which deprives the terrain under discussion of significant individuality, as compared with other European mountains. These declining plants are known already only from few localities in the Karkonosze Mts. and all of them belong to the group of threatened species.

Another strongly marked feature in the non-forested belts is the decline of terricolous bryophytes and lichens. From phytocoenoses retreat or drastically reduce their cover such characteristic and once common mosses, e.g., Dicranum scoparium, Pleurozium schreberii, Hylocomium splendens and Politrychum spp., and epigeic lichens like Cetraria spp. div., Cladonia and Cladina spp. div., Thamnolia vermicularis and Alectoria ochroleuca. This caused an almost total decline of the ground layer of cryptogamic plants and lichens in almost all the communities studied. This process is particularly strongly marked in Carici-Nardetum and Empetro-Vaccinietum, where during the last 35 years the cover of the bryophytes and lichens layer decreased more than ten times. The elimination of the ,d" layer leads to the decline of specific microhabitats, retaining moisture and preventing erosion during moist periods, and during drought conduces to deflation of whole turfs and fragments of vegetation.

A simplified picture of floristic changes in various vegetation belts in the Karkonosze Mts. is presented in Figure 5.

Similar changes, like those presented above for the Karkonosze Mts. phytocoenoses, have also been described in many forested and non-forest communities of eastern, central and northern Europe, for example, in the high

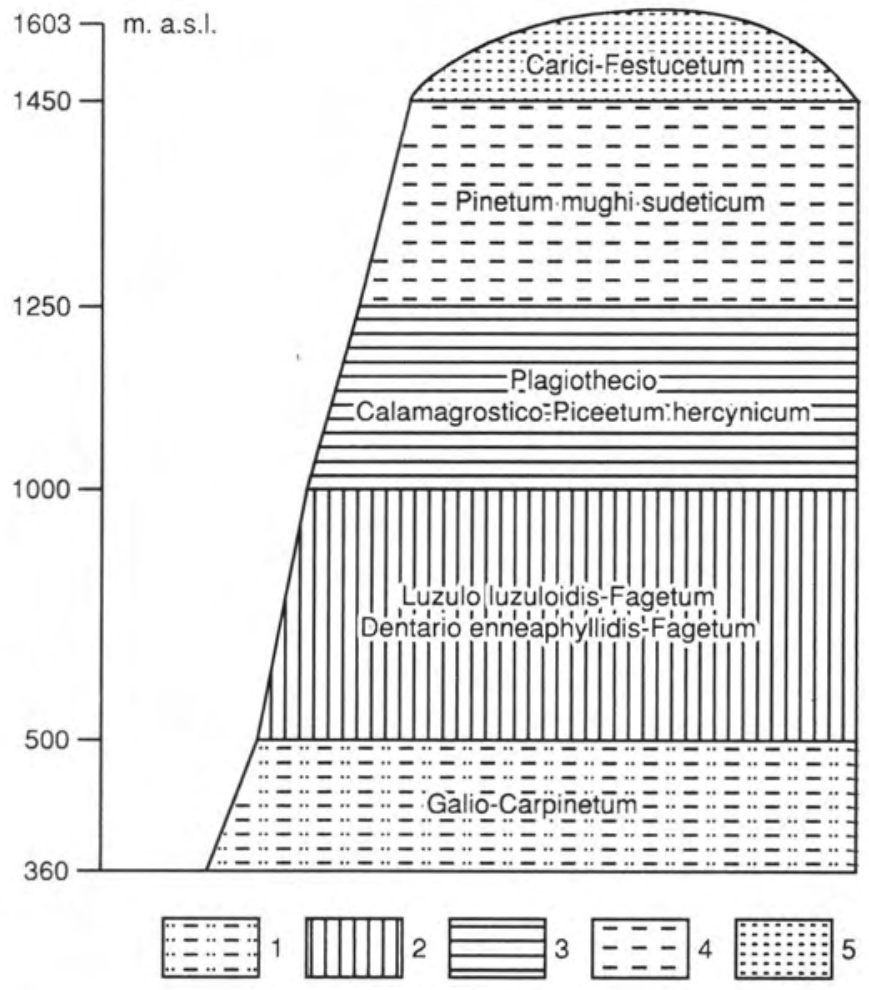

Deschampsia flexuosa

Hieracium alpinum

Deschampsia flexuosa

Senecio nemorensis

Polygonum bistorta

Homogyne alpina

Pulsatilla alba

Calamagrostis villosa

Athyrium distentifolium

Streptopus amplexifolius

Blechnum spicant

Calamagrostis arundinacea

Dentaria ssp. div.

Gymnocarpium dryopteris

Calamagrostis epigeios

Galeobdolon luteum

Fig. 5. Examples of invasive and retreat (italics) plants against a background of vegetation belts in the Karkonosze Mts. $1-$ submontane belt, 2 - low mountain belt, 3 - high mountain belt, 4 - subalpine belt, 5 - alpine belt. 
mountain phytocoenoses of the Czech part of Karkonosze Mts. (Štursova 1985; Štursova, Kocianova 1995), in the Alps' swards (Hegg 1984; Dahler 1992a, b) and in the Czech spruce forests (Kubíková 1989), in Germany (Heinsdorf 1993), and in Scandinavia (Rosén et al. 1992).

\section{Ecological consequences of excessive nitrogen supply}

The recorded by us inflow of mineral nitrogen to the Karkonosze Mts. ecosystems, as compared with the Tatra Mts., burdens with that element the high mountain soils. This is revealed in the mineralization of nitrogen and in the predominance of nitrification and in consequence in a higher content of nitrates in the association Carici-Nardetum.

The high mineralization rate in Carici-Nardetum swards is probably the result of the long lasting in this territory large inflow of mineral nitrogen from the atmosphere. Many authors point to the stimulating influence of permanent nitrogen inflow upon the mineralization process of organic matter, particularly in habitats with shortage of this element (Hanson et al. 1994; Aber et al. 1998). The higher content of nitrogen in organic matter (over 1.4\%) makes it more susceptible to decomposition (Haynes 1986). As Bieńkowski (1995) notifies, the concentration of total $\mathrm{N}$ in the above ground parts in three grasses Deschampsia flexuosa, Calamagrostis villosa and Nardus stricta in the Karkonosze Mts. is 1.85 to $2.07 \%$. The produced organic matter is probably susceptible to rapid decomposition and release of soil nitrogen, particularly $\mathrm{NH}_{4}$ ions (Haynes 1986; Chapin et al. 1995). Thus, it can be stated that large amounts of nitrogen flowing up together with rains to the Karkonosze Mts. swards increased not only the accessible pool of nitrogen saturation, but also changed the quality of organic matter. It simply became more susceptible to decomposition and release of nitrogen. The evidence supporting this view is, in the vegetation season, the found correlation of decomposition of fresh organic matter and mineralization rate in the Karkonosze Mts. subalpine belt with amount of nitrogen forms flowing up from the atmosphere, particularly in ammonium form (Pietr et al. 1995). The importance of $\mathrm{NH}_{4}$ accessibility during nitrification has been noticed in other terrains by Haynes (1986), Tamm (1991) and Nadelhoffer et al. (1997).

Hence, the reason of the high nitrification role in soils of Carici-Nardetum swards is the large amount of substance produced during mineralization of organic nitrogen and the inflow of ammonium ions from the atmosphere.

The outcome of high nitrification rate is the considerable content of nitrates in soil, which together with decomposition of mineral nitrogen stimulate the expansion of plants, capable of rapid use of the increasing amounts of nitrogen. Such plants are, most certainly, grasses, which are of highest negative importance in transformation of floristic composition in Karkonosze Mts. communities (Fig. 3). Rosén et al. (1992) have also observed a close relation between the growth of Deschampsia flexuosa floor vegetation in Swedish spruce forests, and excess of soil critical loads of nitrogen (mainly nitrates) in soils. The increase of the cover of fast growing grass species as response to inflow of mineral components, particularly nitrates, is mainly noted in habitats from nature short in mineral elements (Jonasson 1992; Press et al. 1995; Shevtsova, Neuvonen 1997).

In the dwarf shrub tundra Press et al. (1998) observed, among others, a high decrease in share of bryophytes, a phenomenon confirmed in our phytocoenoses. The reason of elimination of terricolous bryophytes and lichens could be the overfertilization of habitats and/or grass competition. Terricolous lichens are usually typical nitrophobic and/or oligotrophic species. The elimination of bryophytes depends probably on light reduction by grasses (Chapin, Korner 1994). The density of the „d" layer decreased most in those Karkonosze Mts. communities, in which a considerable increase of grass cover took place, i.e., in swards Carici-Nardetum and Carici-Festucetum supinae, and in a lower degree in dwarf shrub heaths Empetro-Vaccinietum.

\section{Reasons of fall of floristic diversity}

The expansion of one or more species causes usually the retreat of other taxa from the community and in result a fall in species abundance of the phytocoenosis (Whittaker 1977; Rosén et al. 1992). In Karkonosze Mts. communities very similar phenomena were observed. The species diversity of communities (expressed by the H' index) decreased by $30-40 \%$, whereas the number of species fell even twice. Species significant for the Karkonosze Mts. flora died out in all the phytocoenoses or occur there only sporadically, that is, species, which in the 60 s were frequently met. This concerns particularly high mountain plants like Diphasiastrum alpinum, Potentilla aurea and Huperzia selago. Long term observations of permanent plots of the association Sieversio-Nardetum from the Alps (Hegg 1984; Dahler 1992a, b) have shown that NPK fertilization was the reason of decline of many, typical for these swards, species, e.g., Amica montana, Solidago virgaurea, Potentilla aurea and Geum montanum.

The decline of rare flora elements and the general impoverishment of the Karkonosze Mts. plant communities have certainly various causes and effects. The presented above data indicate the significant role of anthropogenic cycling of nitrogen in ecosystems. The subsistence of a high diversity of species in phytocoenoses depends among others on spatial environmental heterogeneity of habitats (Tilman 1985). In ecosystems abundant in microhabitats there persists usually a higher number of species than in homogenic habitats. The simple geological structure of the Karkonosze Mts., the rather uniform soil cover, and the poorly diversified microrelief, never classified that massif among mountains of high biodiversity. It is, however, a massif of distinct individual and peculiar character of flora and vegetation cover. The anthropogenic changes tending towards a fall of the Karkonosze Mts. biodiversity and domination of their vegetation by several species of monocots is highly unfavourable for ecosystem structure, particularly in the subalpine and alpine belts.

\section{LITERATURE CITED}

ABER J., MCDOWELL W., NADELHOFFER K., MAGILL A., BERNTSON G., KAMAKEA M., MCNULTY S., CURRIE W., RUSTAD L., FERNANDEZ I. 1998. Nitrogen saturation in temperate forest ecosystems. BioScience 48 (11): 921-934.

BIEŃKOWSKI P. 1995. Zmiany składu elementarnego i zawartości siarki w dominujących gatunkach traw w wybranych punktach Karkonoszy. In: J. Sarosiek (ed.) Geoekologiczne Problemy Karkonoszy, pp. 183-186. Wydawnictwo „Acarus”, Poznań. 
BREJ T., FABISZEWSKI J. 1997. Zmiany antropogeniczne różnorodności roślinnej w Masywie Śnieżnika Annales Silesiae 27: 63-74

CHAPIN, III F.S., KÖRNER C. 1994. Arctic and alpine biodiversity: patterns, causes and acosystem consequences. TREE 9 (2): 45-47.

CHAPIN III F.S., HOBBIE S.E., BRET-HARTE M.S., BONAN G. 1995. Causes and consequences of plant functional diversity in arctic ecosystems. In: F.S. Chapin III and C. Körner (eds), Arctic and alpine biodiversity: pattern, causes and ecosystem consequences, Ecological Studies 113, pp. 225-238. Springer-Verlag, Berlin-Budapest.

DÄHLER W. 1992a. Long term influence of fertilization in a Nardetum. The management of great quantities of data from permanent plots. Vegetatio 103: 135-140.

DÄHLER W. 1992b. Long term influence of fertilization in a Nardetum. Results from the test plots of Dr. W. Lüdi on the Schynige Platte. Vegetatio 103: 141-150.

FABISZEWSKI J., WOJTUŃ B., ŻOŁNIERZ L., MATUŁA J., SOBIERAJSKI Z. 1993. Zmiany ilościowe roślin runa sudeckiego boru górnoreglowego w drzewostanach o różnym stopniu degradacji. In: Z. Fischer, Karkonoskie Badania Ekologiczne, I Konferencja, pp. 77-85. Oficyna Wydawnicza IE, Dziekanów Leśny

FABISZEWSKI J., JENIK J. 1994. Wartości przyrodnicze i zagrożenia Karkonoskiego Parku Narodowego Kosmos 43 (1): 101-115.

FABISZEWSKI J., WOJTUŃ B. 1994. Zjawiska ekologiczne towarzyszące wymieraniu lasów w Sudetach Prace IBL ser. B 21:195-209.

HANSON G.C., GROFFMAN P.M., GOLD A.J. 1994. Symptoms of nitrogen saturation in a riparian wetland. Ecological Applications 4: 750-756.

HAYNES R.J. 1986. Mineral nitrogen in the plant-soil system. 483 pp. AP, Inc., Orlando.

HEGG O. 1984. Langfristige Auswirkungen von Düngung auf einige Arten des Nardetums auf der Schynigen Platte ob Interlaken. Angew. Botanik 58, 141-146.

HEINSDORF D. 1993. The role of nitrogen in declining Scots pine forests (Pinus sylvestris) in the lowland of East Germany. Water, Air, and Soil Pollution 69: 21-35.

JONASSON S. 1992. Plant responses to fertilization and removal in tundra related to community structure and clonality. Oikos 63: 420-429.

KMIEĆ G., KACPERCZYK K., ZWOŹDZIAK J., ZWOŹDZIAK A. 1994. Ocena stężenia i rodzaju zanieczyszczeń w opadach atmosferycznych w rejonie Karkonoszy In: Z. Fischer (ed.), Karkonoskie Badania Ekologiczne II Konferencja, pp. 77-96. Oficyna Wydawnicza IE PAN, Dziekanów Leśny.

KUBIKOVÁ J. 1989. Forest dieback in Czechoslovakia. In: E. Sjögren (ed.). Forest of the World: diversity and dynamics (Abstracts). Studies in Plant Ecology 18, pp. 147-149. Almquist and Wiksell International, Stockholm.

MATUSZKIEWICZ W., MATUSZKIEWICZ A. 1969. Mapa roŚlinności naturalnej Karkonoskiego Parku Narodowego. 60 pp. Mscr.

MATUSZKIEWICZ W., MATUSZKIEWICZ A. 1974. Mapa zbiorowisk roślinnych Karkonoskiego Parku Narodowego. Ochrona Przyrody 40: 45-109.

MIREK Z., PIĘKOŚ-MIRKOWA H. 1995. Szata roślinna Tatr Polskich. In: Z. Mirek and J. J. Wójcicki (eds), Szata Roślinna Parków narodowych i rezerwatów Polski południowej, pp 73150. PAN, Kraków.

MIREK Z., PIĘKOŚ-MIRKOWA H., ZAJĄC A. 1995. Vascucal plants of Poland a checklist. Polish Botan. Studies, Guidebook Series, 15: 3-303. PAN, Kraków.
NADELHOFFER K.J., SHAVER G.R., GIBLIN A., RASTETTER E.B. 1997. Potential impacts of climate change on nutrient cycling, decomposition, and productivity in arctic ecosystems. In: W.C. Oechel, T. Callaghan, T. Gilmanov, J.I. Holten, B. Maxwell, U. Molau, B. Sveinbjörnsson, Global change and arctic terrestrial ecosystems, Ecological Studies 124, pp. 349-364. Springer-Verlag, Berlin.

PEGTEL D.M. 1994. Habitat characteristics and the effect of various nutrient solutions on growth and mineral nutrition of Amica montana $\mathrm{L}$. grown on natural soil. Vegetatio 114: 109-121.

PICCOLO M., NEILL C., CERRI C. 1994. Net nitrogen mineralization and net nitrification along a tropical forest-to-pasture chronosequence. Plant and Soil 162: 61-70.

PIETR S.J., FISCHER Z., TYRAWSKA D., BAJAN C. 1995. Biologiczne procesy rozkładu substancji organicznej w glebach Karkonoszy. In: Z. Fischer (ed.), Problemy ekologiczne wysokogórskiej części Karkonoszy, pp. 131-168. Oficyna Wydawnicza IE PAN, Dziekanów Leśny.

PRESS M.C., POTTER J.A. BURKE M.J.W., CALLAGHAN T.V., LEE J.A. 1998. Responses of subarctic dwarf shrub heath community to simulated environmental change. Journal of Ecology 86: 315-327.

ROSÉN K., GUNDERSEN P., TENGHAMMAR L., JOHANSSON M., FROGNER T. 1992. Nitrogen enrichment in nordic forest ecosystems. Ambio 21: 364-368.

SCHUBE T. 1903. Die Verbreitung der Gefäßpplanzen in Schlesien. R. Nischkowsky. Breslau, pp. 362.

SCHWABE A. 1990. Syndynamische prozesse in borstgrassen: reaktionsmuster von brachen nach erneuter rinderbeweidung und lebensrhythmus von Amica montana L. Carolinea 48: 45-68.

SHEVTSOVA A., NEUVONEN S. 1997. Responses of ground vegetation to prolonged simulated acid rain in sub-arctic pinebirch forest. New Phytologist 136: 613-625.

ŠTURSOVÁ H. 1985. Antropické vlivy na strukturu a vývoj smilkových luk v Krkonošich. Opera Corcontica 22: 79-120.

ŠTURSOVÁ H., KOCIÁNOVÁ M. 1995. Changes of the tundra on Studniční hora and Bílá louka. In: L. Soukupová, M. Kociánová, J. Jenik and J. Sekyra (eds.). Arctic-alpine tundra in the Krkonoše, The Sudetes. Opera Corcontica 32: 69-72.

TAMM C.O. 1991. Nitrogen in terrestrial ecosystems. Ecological Studies 81, 115 pp. Springer-Verlag, Berlin.

TILMAN D. 1985. The resource-ratio hypothesis of plant succesion. Am. Nat. 125: 827-852.

WATHNE B.E., MILL W.A., KOT M., RZYCHON D., HENRIKSEN A., TØRSETH K. 1993. Critical loads of acidity to lakes in the Polish Tatra Mountains. NIVA Report 33, pp. 37.

WHITTAKER R.H. 1977. Evolution of species diversity in land communities. In: M.K. Hecht, W.C. Steere and B. Wallace (eds). Evolutionary biology, Vol. 10, pp. 1-67. New York.

WOJTUŃ B., FABISZEWSKI J., SOBIERAJSKI J., MATUŁA J., ŻOŁNIERZ L. 1995. Współczesne przemiany wysokogórskich fitocenoz Karkonoszy. In: Z. Fischer (ed.), Problemy ekologiczne wysokogórskiej części Karkonoszy, pp. 213-246. Oficyna Wydawnicza IE PAN, Dziekanów Leśny.

WOJTUŃ B., MATUŁA J., ŻOŁNIERZ L. 1997. Procesy ekologiczne decydujące o przemianach wysokogórskich zbiorowisk roślinnych Karkonoszy. Annales Silesiae 27: 97-121. Zwoździak J., Kmieć G., Zwoździak A., Kacperczyk K. 1995. Presja zanieczyszczeń przemysłowych w ostatnim wieloleciu a stan obecny. In: Z. Fischer (ed.), Problemy ekologiczne wysokogórskiej części Karkonoszy, pp. 79-96. Oficyna Wydawnicza IE PAN, Dziekanów Leśny.

ŻOŁNIERZ L., FABISZEWSKI J., MATUŁA J., SOBIERAJSKI Z., WOJTUŃ B. 1994. Bioindykacja opadu metali ciężkich i siarki w górnoreglowych borach Karkonoszy. In: Z. Fischer, Karkonoskie Badania Ekologiczne, II Konferencja, pp. 191202. Oficyna Wydawnicza IE, Dziekanów Leśny. 


\section{WSPÓŁCZESNE PRZEMIANY W SKŁADZIE FLORY KARKONOSZY}

\section{STRESZCZENIE}

W pracy przedstawiono zmiany składu gatunkowego w głównych zbiorowiskach roślinnych Karkonoszy w piętrze subalpejskim i alpejskim w ostatnich 35 latach. Postępujące w ciągu tego czasu ubożenie i dgradacja zbiorowisk roślinnych wyrażają się ekspansją kilku gatunków traw, zanikaniem wielu typowych naczyniowych gatunków górskich oraz eliminacją naziemnych mszaków i porostów. W reglu górnym znamienne jest wypieranie roślin naczyniowych związanych ze starymi borami świerkowymi, jak Listera cordata i Moneses uniflora. W niższych piętrach zmiany częśsiowo wynikają z zaniechania wypasu i koszenia na łąkach górskich (np. zanik stanowisk Arnica montana). Główną przyczyną przemian flory i szaty roślinnej są jednak zmiany środowiska glebowego związane $\mathrm{z}$ antropogenicznym transportem azotu. Opad mineralnego azotu, wynoszący $1138 \mathrm{mg} / \mathrm{m}^{2} \mathrm{w}$ ciągu sezonu wegetacyjnego, powoduje szybszy rozkład materii organicznej i intensywną nitryfikację. Antropogeniczne przenawożenie Karkonoszy jest prawdopodobnie głównym czynnikiem sprawczym zaniku wielu miejscowych gatunków górskich jak również intensywnej ekspanji traw.

SŁOWA KLUCZOWE: Karkonosze, flora, bioróżnorodność, mineralizacja azotu, nitryfikacja. 